\title{
HUBUNGAN PERSONAL HYGIENE DENGAN KEBERADAAN ESCHERICHIA COLI PADA MAKANAN DI TEMPAT PENGOLAHAN MAKANAN (TPM) BUFFER AREA BANDARA ADI SOEMARMO SURAKARTA
}

\author{
ASSCOCIATION OF PERSONAL HYGIENE WITH THE PRESENCE OF EScherichia \\ coli IN FOOD PROCESSING (TPM) BUFFER AREA ADI SOEMARMO AIRPORTS \\ SURAKARTA
}

\author{
Fitka Romanda, Priyambodo, Erika Diana Risanti \\ Fakultas Kedokteran Universitas Muhammadiyah Surakarta \\ Korespondensi: dr. Erika Diana Risanti, Email: erika.d.risanti@ums.ac.id
}

\begin{abstract}
ABSTRAK
Keberadaan Escherichia coli dalam sumber air atau makanan merupakan indikasi pasti terjadinya kontaminasi tinja manusia. Kontaminasi ini dapat berdampak pada Kejadian Luar Biasa keracunan makanan di negara berkembang, termasuk di Indonesia. Adanya kontaminasi Escherichia coli pada makanan dapat disebabkan faktor personal hygiene penjamah makanan yang kurang baik. Penelitian ini bertujuan untuk mengetahui adanya hubungan personal hygiene penjamah makanan dengan Escherichia coli. Penelitian ini menggunakan metode observasional dengan pendekatan cross sectional. Subyek penelitian adalah 65 penjamah makanan dan 65 sampel makanan di 22 tempat pengolahan makanan buffer area Bandara Adi Soemarmo Surakarta. Hasil penelitian menunjukan adanya hubungan personal hygiene dengan keberadaan Escherichia coli pada makanan di Tempat Pengolahan Makanan Buffer Area Bandara Adi Soemarmo Surakarta dengan uji statistik dengan Chi Square didapatkan p value $(0,000)$ dan kekuatan hubungan sedang dengan nilai $C(0,477)$. Berdasarkan hasil penelitian, disimpulkan terdapat hubungan personal hygiene penjamah makanan dengan keberadaan Escherichia coli pada makanan di tempat pengolahan makanan (TPM) buffer area Bandara Adi Soemarmo Surakarta.
\end{abstract}

Kata kunci. Personal Hygiene, Escherichia coli, Buffer Area

\section{ABSTRACT}

The existence of Escherichia coli in water or food is a definite indication of human fecal contamination by Escherichia coli which can have an impact on Extraordinary Events food poisoning in developing countries, especially in Indonesia. Escherichia coli contamination in food can be caused by other worst personal hygiene factor offood handlers. Aim of this research is to know the relation of personal hygiene's food handlers relationship Escherichia coli. This study was an observational study with cross sectional approach. The research subjects are 65 of food handlers and 65 samples of food at 22 Place Food Processing Buffer Area Adi Soemarmo Airports Surakarta. The results showed the existence of a personal relationship with the presence of Escherichia coli hygiene in food at the Food Processing Buffer Area Sites Adi Soemarmo Surakarta with the statistical test used is Chi Square test and got $p$ value (0.000) and the strength of relationship is with the C (0.477). Based on the results of the study, concluded there is a relationship of personal hygiene of food handlers to the presence of Escherichia coli in foods in the food processing (TPM) buffer area Adi Soemarmo Surakarta.

Keywords. Personal Hygiene, Escherichia coli, Buffer Area

\section{PENDAHULUAN}

Makanan merupakan salah satu kebutuhan pokok manusia untuk dapat melangsungkan kehidupan selain kebutuhan sandang dan papan. Selain mengandung nilai gizi yang dibutuhkan oleh tubuh, makanan merupakan media yang baik dalam kontaminasi dan perkembang biakan bakteri karena mengandung kadar air serta nilai protein yang tinggi (Depkes, 2010). 
Peningkatan jumlah usaha restoran dan rumah makan dari 2009 yaitu tercatat sebanyak 2704 menjadi 2916 di tahun 2010, dengan keadaan seperti ini jasa boga yang sudah ada harus menjamin kualitas makanan, higiene perorangan, dan sanitasi makanan (Kemenkeu, 2012).

Departemen Kesehatan menyatakan bahwa kualitas makanan baik secara bakteriologis, kimiawi maupun fisik harus selalu dipertahankan. Keberadaan Escherichia coli dalam sumber air atau makanan merupakan indikasi pasti terjadinya kontaminasi tinja manusia sehingga $E$. Coli dipilih sebagai indikator mikrobiologi tercemarnya air atau makanan. Angka kuman Escherechia coli pada makanan 0 per gram contoh makanan (Chandra, 2006; Nugroho, 2011; Depkes, 2003).

Terjadi peningkatan kasus keracunan makanan akibat mengonsumsi makanan terkontaminasi oleh E. coli. Di Amerika sekitar 48 juta kasus per tahun penyakit bawaan makanan, Di Indonesia sendiri berdasarkan BPOM insiden terbanyak kasus keracunan disebabkan oleh makanan kasus yang terjadi di tahun 2014 mencapai lebih dari 500 kasus. Tahun 2011 dilaporkan 18.144 orang terpapar, sedangkan kasus Kejadian Luar Biasa (KLB) keracunan pangan yang dilaporkan sebanyak 6.901 orang sakit dan 11 orang meninggal dunia. WHO menyebutkan bahwa setiap satu kasus yang berkaitan dengan KLB keracunan pangan di suatu negara berkembang, paling tidak terdapat 99 kasus yang tidak dilaporkan (FDA, 2015).

Dalam penelitian Fitri Hermastuti mengenai faktor risiko kontaminasi Escherichia coli di rumah makan kecamatan Semarang kota Semarang didapatkan hubungan antara personal hygiene penjamah dengan keberadaan E.coli. Cahyaningsih (2009) menyatakan bahwa terdapat hubungan mencuci tangan sebelum bekerja, mencuci tangan tanpa sabun setelah $\mathrm{BAB}$ atau BAK, dan kebiasaan menuci tangan dengan kualitas bakteri. Dari penelitian Kurniadi tenaga penjamah yang tidak memenuhi syarat mempunyai peluang terkontaminasi $E$. coli sebanyak 4,5 kali dibandingkan dengan tenaga penjamah yang memenuhi syarat (Hermastuti, 2006; Cahyaningsih, et al, 2009; Kurniadi, 2013 ).

Wilayah penyangga (Buffer Zone) Pelabuhan atau Bandar Udara merupakan wilayah yang mengelilingi atau berdampingan dengan Daerah Lingkungan Kerja (DLKr) Pelabuhan atau Bandar Udara. Penyehatan lingkungan wilayah ini dimaksudkan untuk melindungi area Pelabuhan atau Bandar Udara dari dampak negatif kegiatan manusia di sekitarnya serta melindungi masyarakat sekitar dari faktor risiko kesehatan masyarakat akibat kegiatan Pelabuhan atau Bandar Udara (Depkes, 2014).

Berdasarkan latar belakang di atas, saya tertarik utuk melakukan penelitian mengenai hubungan personal hygiene penjamah makanan dengan keberadaan Escherichia coli pada makanan di Tempat Pengolahan Makanan (TPM) Buffer Area Bandara Adi Soemarmo Surakarta.

\section{METODE}

Penelitian ini menggunakan metode observasional dengan pendekatan cross sectional. Dilakukan observasi pada 65 penjamah makanan dan pengambilan 65 sampel makanan di 22 Tempat Pengolahan Makanan Buffer Area Bandara Adi Soemarmo Surakarta.Uji statistik yang digunakan adalah uji Chi Square.

\section{HASIL DAN PEMBAHASAN}

Data penelitian ini diperoleh hasil karakteristik dasar subjek penelitian berdasarkan usia, jenis kelamin, dan pendidikan sebagai berikut:

Pada tabel 1, usia responden paling banyak berusia 31-40 tahun yaitu sebanyak 28 orang $(43,1 \%)$ dan paling sedikit berumur kurang dari 20 tahun yaitu sebanyak 1 orang (1,5\%).

Tabel 1. Karakteristik Responden Berdasarkan Umur

\begin{tabular}{cccc}
\hline No & Usia & Jumlah & Persentase \\
\hline 1 & $<20$ tahun & 1 & 1,5 \\
2 & $20-30$ tahun & 25 & 38,5 \\
3 & $31-40$ tahun & 28 & 43,1 \\
4 & $41-50$ tahun & 8 & 12,3 \\
5 & $>50$ tahun & 5 & 4,6 \\
\hline & Jumlah & 65 & 100 \\
\hline
\end{tabular}

Pada Tabel 2, menunjukkan bahwa mayoritas responden berumur berjenis kelamin perempuan yaitu sebanyak 38 orang $(58,5 \%)$. 
Tabel 2. Karakteristik Responden Berdasarkan Jenis Kelamin

\begin{tabular}{llll}
\hline No & Jenis kelamin & Jumlah & Persentase \\
\hline 1 & Laki-laki & 27 & 41,5 \\
2 & Perempuan & 38 & 58,5 \\
\hline & Jumlah & 65 & 100 \\
\hline
\end{tabular}

Pada tabel 3, menunjukkan bahwa mayoritas responden berpendidikan SD yaitu sebanyak 36 orang $(55,4 \%)$ dan yang berpendidikan D3 hanya 1 orang $(1,5 \%)$.

Tabel 3. Karakteristik Responden Berdasarkan Pendidikan

\begin{tabular}{llll}
\hline No & Pendidikan & Jumlah & Persentase \\
\hline 1 & SD & 36 & 55,4 \\
2 & SMP & 17 & 26,2 \\
3 & SMA & 11 & 16,9 \\
4 & D3 & 1 & 1,5 \\
\hline & Jumlah & 65 & 100 \\
\hline
\end{tabular}

Hasil analisis univariat personal hygiene dan keberadaan Escherichia coli didapatkan sebagai berikut:

Tabel 4 menunjukkan hasil observasi praktik penjamah makanan dan ada beberapa praktik yang sebagian besar tidak dilakukan penjamah di Tempat Pengolahan Makanan (TPM) buffer area Bandara Adi Soemarmo Surakarta antara lain : $(98,5 \%)$ penjamah tidak memakai pakaian kerja pada saat bekerja, $(95,4 \%)$ tidak memakai celemek pada saat bekerja, (66,2\%) penjamah tidak memperhatikan kebersihan peralatan sebelum digunakan (mencuci peralatan), $(64,6 \%)$ penjamah kukunya tidak terpelihara pendek, $(58,5 \%)$ penjamah makanan tidak memakai tutup kepala saat bekerja.

Tabel 4. Distribusi Frekuensi Personal Hygiene Penjamah Makanan di Tempat Pengolahan Makanan (TPM) buffer area Bandara Adi Soemarmo Surakarta

\begin{tabular}{|c|c|c|c|c|c|}
\hline \multirow{2}{*}{ No } & \multirow{2}{*}{ Pertanyaan } & \multicolumn{2}{|c|}{ Dilakukan } & \multicolumn{2}{|c|}{ Tidak dilakukan } \\
\hline & & $\mathrm{F}$ & $\%$ & $\mathrm{~F}$ & $\%$ \\
\hline 1 & $\begin{array}{l}\text { Penjamah makanan mencuci tangan dengan sabun } \\
\text { sebelum menangani makanan }\end{array}$ & 40 & 61,5 & 25 & 38,5 \\
\hline 2 & $\begin{array}{l}\text { Penjamah makanan mencuci tangan dengan sabun } \\
\text { setelah keluar dari WC atau kamar kecil }\end{array}$ & 65 & 100 & 0 & 0 \\
\hline 3 & $\begin{array}{l}\text { Penjamah makanan mencuci tangan dengan sabun } \\
\text { setelah meracik bahan mentah }\end{array}$ & 41 & 63,1 & 24 & 36,9 \\
\hline 4 & Tidak mengeringkan tangan dengan celemek & 45 & 69,2 & 20 & 30,8 \\
\hline 5 & $\begin{array}{l}\text { Memperhatikan kebersihan peralatan sebelum } \\
\text { digunakan (mencuci peralatan) }\end{array}$ & 22 & 33,8 & 43 & 66,2 \\
\hline 6 & Memakai pakaian kerja pada saat bekerja & 1 & 1,5 & 64 & 98,5 \\
\hline 7 & Memakai celemek saat bekerja & 3 & 4,6 & 62 & 95,4 \\
\hline 8 & Memakai tutup kepala saat bekerja & 27 & 41,5 & 38 & 58,5 \\
\hline 9 & Tidak berbicara saat bekerja & 42 & 64,6 & 23 & 35,4 \\
\hline 10 & Kuku terpelihara pendek & 23 & 35,4 & 42 & 64,6 \\
\hline 11 & $\begin{array}{l}\text { Penjamah makanan tidak memakai perhiasaan misal } \\
\text { cincin atau gelang saat bekerja, kecuali cincin kawin }\end{array}$ & 41 & 63,1 & 24 & 36,9 \\
\hline 12 & Tidak memakan makanan saat bekerja & 53 & 81,5 & 12 & 18,5 \\
\hline 13 & Membersihkan tempat setelah selesai kegiatan & 52 & 80 & 13 & 20 \\
\hline
\end{tabular}

Keterangan F: Frekuensi 
Personal hygiene penjamah makanan di tempat pengolahan makanan (TPM) buffer area Bandara Adi Soemarmo Surakarta kemudian dikategorikan menjadi kurang baik dan baik, hasil pengkategorian selengkapnya dapat dilihat pada tabel 5. Dari tabel 5, diketahui bahwa sebagian besar penjamah makanan di Tempat Pengolahan Makanan (TPM) buffer area Bandara Adi Soemarmo Surakarta mempunyai personal hygiene baik yaitu sebanyak 51 orang $(78,5 \%)$, dan yang 14 orang $(21,5 \%)$ mempunyai personal hygiene kurang baik.

Tabel 5. Distribusi Frekuensi Personal Hygiene

Penjamah Makanan di Tempat Pengolahan

Makanan (TPM) buffer area Bandara Adi Soemarmo.

\begin{tabular}{llcc}
\hline No & $\begin{array}{c}\text { Praktik Personal } \\
\text { Hygiene }\end{array}$ & $\mathrm{F}$ & $\%$ \\
\hline 1 & Tidak Baik & 14 & 21,5 \\
2 & Baik & 51 & 78,5 \\
Total & & 65 & 100 \\
\hline
\end{tabular}

Dari tabel 6. diketahui bahwa sebagian besar sampel makanan di Tempat Pengolahan Makanan (TPM) buffer area Bandara Adi Sumarmo Surakarta tidak ditemukan (tidak ada) Escherichia coli yaitu sebanyak 58 sampel $(89,2 \%)$, dan yang ditemukan (ada) Escherichia coli yaitu sebanyak 7 sampel $(10,8 \%)$.

Tabel 6. Distribusi Frekuensi Keberadaan Escherichia coli pada Sampel Makanan di Tempat Pengelolaan Makanan (TPM) buffer area Bandara Adi Soemarmo Surakarta

\begin{tabular}{llcc}
\hline \multirow{2}{*}{ No } & \multicolumn{1}{c}{$\begin{array}{c}\text { Keberadaan } \\
\text { Escherichia coli }\end{array}$} & F & $\%$ \\
\hline 1 & Ada & 7 & 10,8 \\
2 & Tidak ada & 58 & 89,2 \\
Total & 65 & 100 \\
\hline
\end{tabular}

Hasil analisis bivariat untuk mengetahui hubungan antara personal hygiene penjamah makanan dengan keberadaan Escherichia coli pada makanan di tempat pengolahan makanan (TPM) buffer area Bandara Adi Sumarmo Surakarta dapat dilihat pada tabulasi silang di bawah ini.

Tabel 7. Tabulasi silang personal hygiene penjamah makanan dengan keberadaan Escherichia coli pada makanan di tempat pengolahan makanan (TPM) buffer area Bandara Adi Sumarmo Surakarta

\begin{tabular}{|c|c|c|c|c|c|c|c|c|c|}
\hline \multirow{3}{*}{ Personal hygiene } & \multicolumn{6}{|c|}{ KeberadaanEscherichia coli } & \multirow{3}{*}{$\chi^{2}$} & \multirow{3}{*}{$\mathrm{p}$} & \multirow{3}{*}{$\mathrm{C}$} \\
\hline & \multicolumn{2}{|c|}{ Ada } & \multicolumn{2}{|c|}{ Tidak Ada } & \multicolumn{2}{|c|}{ Total } & & & \\
\hline & $\mathrm{f}$ & $\%$ & $\mathrm{~F}$ & $\%$ & $\mathrm{f}$ & $\%$ & & & \\
\hline Kurangbaik & 6 & 42,9 & 8 & 57,1 & 14 & 100 & 19,119 & 0,000 & 0,477 \\
\hline Baik & 1 & 2 & 50 & 98 & 51 & 100 & & & \\
\hline
\end{tabular}

Hasil penelitian ini menunjukkan bahwa ada hubungan personal hygiene penjamah makanan dengan keberadaan Escherichia coli pada makanan di tempat pengolahan makanan (TPM) buffer area Bandara Adi Soemarmo Surakarta $(\mathrm{p}=0,000 ; \mathrm{p}<0,05)$. Tingkat keeratan hubungan keduanya sedang $(\mathrm{C}=0,477 ; \mathrm{C}<0,5)$. Hasil penelitian ini berbanding terbalik dengan penelitian Pratiwi bahwa tidak ada hubungan antara kebersihan diri penjamah makanan dengan Escherichia coli.

Penelitian ini dilakukan dengan tujuan mengetahui hubungan personal hygiene penjamah makanan dengan keberadaan Escherichia coli pada makanan di Tempat Pengolahan Makanan Buffer Area Bandara Adi Soemarmo Surakarta. Pembahasan dari hasil penelitian sebagai berikut:
Salah satu penyebab personal higiene penjamah makanan buruk diantarannya tidak memakai penutup rambut. Dari hasil penelitian dapat diketahui sebanyak $(58,5 \%)$ penjamah makanan tidak memakai tutup kepala saat bekerja. Hal ini bisa terjadi kontaminasi silang apabila rambut dibiarkan dalam proses memasak. Dari hasil penelitian dapat diketahui sebanyak $66,2 \%$ penjamah tidak memperhatikan kebersihan peralatan sebelum digunakan (mencuci peralatan), hal ini dapat menjadi sumber kontaminasi bakteri dari peralatan yang kotor ke makanan. Dari hasil penelitian dapat diketahui sebanyak $64,6 \%$ penjamah kukunya tidak terpelihara pendek, pada saat menjamah makanan hal ini yang menyebabkan perpindahan bakteri dari tangan ke makanan langsung. 
Peraturan BPOM (2015) menjelaskan bahwa semua pekerja yang menjamah makanan diharuskan mencuci tangan dengan sabun, air mengalir, dan dikeringkan. Hasil penelitian ditemukan $61,5 \%$ penjamah makanan mencuci tangan dengan sabun sebelum menangani makanan. Pekerja penjamah makanan menjadi faktor penting dalam proses kontaminasi makanan. Kesehatan dan pengolahan makanan mempunyai pengaruh besar pada mutu produk yang disajikannya sehingga hal ini perlu mendapatkan perhatian khusus. Sylvia Angubua Baluka dkk (2015) mengemukakan bahwa penyebaran penyakit melalui makanan dikaitkan dengan praktik penjamah makanan yang tidak tepat pada saat menyajikan makanan (Baluka, 2015).

Penjamah makanan (food handler) merupakan sumber utama kontaminasi makanan. Tangan, mulut, rambut, dan kulit dapat mencemari makanan. Kontaminasi makanan tersebut dapat berasal dari berbagai macam sumber kontaminasi silang, seperti transmisi dari daging mentah ke makanan siap saji. Keberadaan Escherichia coli pada rawon dapat disebabkan karena daging merupakan media yang sangat baik untuk pertumbuhan bakteri dan dapat dijadikan sebagai indikator adanya kontaminasi bakteri patogen yang berkaitan dengan sanitasi (Arnia, 2013)

Kebersihan tangan penjamah makanan perlu diperhatikan, seperti tangan yang kotor berkuku panjang. Selain itu perlu diperhatikan juga kebiasaan tidak mencuci tangan dengan sabun sebelum menjamah makanan dan setelah dari toilet. Perhiasan yang digunakan dapat menjadi tempat berkumpulnya bakteri. Selain itu perhiasan dapat jatuh ke dalam makanan yang diolah sehingga dapat menimbulkan kontaminasi makanan.

Mencuci tangan sebelum mengolah makanan dianggap efektiv dalam mengurangi risiko kontaminasi bakteri patogen. Dalam penelitian Burton mencuci tangan menggunakan air dan sabun dapat menurunkan angka keberadaan bakteri sebanyak $8 \%$ dan terbukti dalam penelitian Mwambete dapat menghambat pertumbuhan bakteri E. coli. Sabun cuci tangan yang banyak beredar mengandung bahan aktif triklosan yang dapat berfungsi sebagai antimikroba (Burton et al, 2011; Mwambete et al, 2011; Wijaya et al, 2013).

Kontaminasi makanan oleh bakteri Escherichia coli dapat menyebar melalui pencemaran air maupun lingkungan. Makanan atau peralatan yang kontak langsung dengan air maupun lingkungan yang tercemar apabila didapatkan hasil laboratorium adanya bakteri Escherichia coli mengindikasikan bahwa makanan tersebut pernah terkontaminasi kotoran manusia (Falamy et al, 2013)

Dalam menunjang praktik yang baik sehingga membentuk perilaku higiene personal yang benar, fasilitas yang disediakan juga sangat mendukung. Fasilitas yang berhubungan dengan higiene penjamah, seperti penyediaan air, tempat mencuci tangan dan sabun, ruang ganti pakaian, kelengkapan pakaian kerja (seragam, clemek, penutup kepala, masker, dan sarung tangan).

Personal hygiene penjamah makanan sangat mempengaruhi keberadaan Escherichia coli pada nasi. Mudey menyatakan sikap yang baik dan benar serta pengetahuan sangat mempengaruhi mutu kualitas makanan dan meningkatnya risiko kontaminasi oleh bakteri. Adapun responden yang mempunyai personal hygiene penjamah baik tetapi makanan mengandung Escherichia coli disebabkan proses penyimpanan yang tidak tepat, dalam penelitian Pagiu dkk 2013 penyimpananan yang disimpan di tempat terbuka akan meningkatkan kontaminasi Escherichia coli sebanyak 2 kali lipat (Mudey et al, 2010).

Tangan penjamah makanan terbukti dalam penelitian Lambrechts dkk 2014 merupakan vektor penyebaran penyakit bawaan makanan. Maka dari itu personal hygiene dapat tercapai apabila dalam diri penjamah makanan tertanam pengertian pentingnya menjaga kesehatan dan kebersihan diri sehingga menghasilkan mutu pangan yang baik (Lambrechts et al, 2014).

\section{SIMPULAN}

Ada hubungan personal hygiene penjamah makanan dengan keberadaan Escherichia coli pada makanan di tempat pengolahan makanan (TPM) buffer area Bandara Adi Soemarmo Surakarta ( $\mathrm{p}$ $=0,000 ; \mathrm{p}<0,05)$.

Sebagian besar penjamah makanan di Tempat Pengolahan Makanan (TPM) buffer area Bandara Adi Sumarmo Surakarta mempunyai personal hygiene baik yaitu sebanyak 51 orang $(78,5 \%)$, dan yang 14 orang $(21,5 \%)$ mempunyai personal hygiene kurang baik. 
Sebagian besar makanan di Tempat Pengolahan Makanan (TPM) buffer area Bandara Adi Soemarmo Surakarta tidak ditemukan (tidak ada) Escherichia coli yaitu sebanyak 58 sampel (89,2\%), dan yang ditemukan (ada) Escherichia coli yaitu sebanyak 7 sampel (10,8\%).

\section{DAFTAR PUSTAKA}

Arnia., Warganegara, E. 2013. Identifikasi Kontaminasi Bakteri Coliform Pada Daging Sapi Segar Yang Dijual Di Pasar Sekitar Kota Bandar Lampung. MAJORITY ;2(5):43-50

Baluka, S. A., Miller, R.A., Kaneene, J. B. 2015. Hygiene Practices And Food Contamination In Managed Food Service Facilities In Uganda. African J Food Sci. 9(1):31-42

Burton, M., Cobb, E., Donachie, P., Judah, G., Curtis, V and Schmidt, W. P. 2011. The Effect of Handwashing with Water or Soap on Bacterial Contamination of Hands. Int. J. Environ. Res. Public Health. 8 (1): 97-104

Cahyaningsih, C.T., Kushadiwijaya, H., Tholib A. 2009. Hubungan Higiene Sanitasi Dan Perilaku Penjamah Makanan Dengan Kualitas Bakteriologis Peralatan Makan Di Warung Makan. Berita Kedokteran Masyarakat, 25(4): 180 - 8

Chandra, B. 2006. Pengantar Kesehatan Lingkungan. Penerbit Buku Kedokteran Jakarta: EGC

Departemen Kesehatan 2003. Keputusan Menteri Kesehatan Republik Indonesia Nomor 1098/ Menkes/ SK/ VII/ 2003 Tentang Persyaratan Hygiene Sanitasi Rumah Makan Dan Restoran. Jakarta: Depkes RI

Depkes RI. 2010. Modul Kursus Hygiene dan Sanitasi Makanan dan Minuman, Departemen Kesehatan Republik Indonesia Ditjen PPM \& PLP. Jakarta: Depkes RI

Depkes RI. 2014. Peraturan Menteri Kesehatan Republik Indonesia Nomor 44 Tahun 2014 Tentang Penyelenggaraan Pelabuhan Dan Bandar Udara Sehat. Jakarta : Depkes RI

Falamy, R., Warganegara, E., Apriliana, E. 2013. Deteksi Bakteri Coliform pada Jajanan Pasar Cincau Hitam di Pasar Tradisional dan Swalayan Kota Bandar Lampung. MAJORITY;2(5):1-9
FDA. 2015. Foodborne Illnesses: What You Need to Know. http://www.fda.gov/Food/ ResourcesForYou/Consumers/ucm103263.htm. Diakses 30 September 2015

Hermastuti, F. 2006. Faktor Risiko Kontaminasi Escherichia Coli Di Rumah Makan Kecamatan Semarang Tengah Kota Semarang (Thesis). Fakultas Kesehatan Masyarakat Universitas Diponegoro

Kementerian Keuangan Republik Indonesia Badan Kebijakan Fiskal. 2012. Kajian Profil Sektor Riil : Sektor Perdagangan, Hotel, dan Restoran.http://www.kemenkeu. go.id/sites/default/files/Profil\%20Sektor\%20 Riil.pdf

Kurniadi, Y, Saam, Z., Afandi, D. 2013. Faktor Kontaminasi Bakteri E.coli Pada Makanan Jajanan Di Lingkungan Kantin Sekolah Dasar Wilayah Kecamatan Bangkinang. Jurnal Ilmu Lingkungan; 7(1):28-37

Lambrechts AA., Human IS., Doughari JH., Lues JFR. 2014. Bacterial contamination of the hands of foodhandlers as indicator of hand washing efficacyin some convenient food industries. Pak J Med Sci . 30(4): 755-8.

Mudey, A. B., Kesharwani, N., Mudey, G A., Goyal, R. C., Dawale, A. K., Wagh V. 2010. Health Status and Personal Hygiene among Food Handlers Working at Food Establishment around a Rural Teaching Hospital in Wardha District of Maharashtra, India. Global Journal of Health Science. 2(2):198-206

Mwambete KD, Lyombe F. 2011. Antimicrobial activity of medicated soaps commonly used by dar es salaam residents in Tanzania. Indian J Pharm Sci.73(1):92-8

Nugroho, M. 2014. Kondisi Higiene Penjamah Makanan Dan Sanitasi Kantin Di SMAN 15 Surabaya. Jurnal Kesehatan Lingkungan. 7(2):166-70

Wijaya, J. I. 2013. Formulasi Sediaan Gel Hand Sanitizer Dengan Bahan Aktif Triklosan 1,5\% dan 2\%. Jurnal Ilmiah Mahasiswa Universitas Surabaya. 2(1):1-14 